Kashif et al., 2020

Volume 6 Issue 2, pp. 609-624

Date of Publication: 22 ${ }^{\text {nd }}$ October 2020

DOI- https://doi.org/10.20319/pijss.2020.62.609624

This paper can be cited as: Kashif, M., Asif, M. U., Ali, A., Asad, M., Asad, M., Chethiyar, S. D. M. E Vedamanikam, M. (2020). Managing and Implementing Change Successfully with Respect to COVID-19: A Way Forward for SMEs. PEOPLE: International Journal of Social Sciences, 6(2), 609-624.

This work is licensed under the Creative Commons Attribution-NonCommercial 4.0 International License. To view a copy of this license, visit http://creativecommons.org/licenses/by-nc/4.0/ or send a letter to Creative Commons, PO Box 1866, Mountain View, CA 94042, USA.

\title{
MANAGING AND IMPLEMENTING CHANGE SUCCESSFULLY WITH RESPECT TO COVID-19: A WAY FORWARD FOR SMES
}

\author{
Muhammad Kashif \\ Lecturer, Department of Management Studies Foundation University Islamabad, Sialkot, Pakistan \\ mkash.kashif@gmail.com
}

Muhammad Uzair Asif

Research Assistant, Faculty of Management and Social Sciences, Capital University of Science and Technology, Islamabad, Pakistan

uzairasif54@gmail.com

\author{
Ahsan Ali \\ MS Scholar Ca' Foscari University of Venice, Venice, Italy \\ ahsanbabar522@gmail.com
}
Muzaffar Asad
Assistant Professor, Department of Management and Marketing, College of Business, University of Bahrain, Zallaq, Bahrain masad@uob.edu.bh

\section{Saralah Devi Mariamdaran Chethiyar}

Senior Lecturer, Psychology \& Counselling Program, School of Applied Psychology, Social Work and Policy, College of Arts and Sciences, Universiti Utara Malaysia, Malaysia devi@uum.edu.my

\section{Mohanamerry Vedamanikam}

Ph.D. Candidate (Psychology), School of Applied Psychology, Social Work and Policy, College of Arts and Sciences, Universiti Utara Malaysia, Malaysia mohanamerry_vedam@ahsgs.uum.edu.my 


\begin{abstract}
The pandemic has changed the way of doing things in the entire world. To survive in situations, we need change. All the organizations are trying their level best to implement change successfully however, all of them are facing severe issues. The purpose of this study is to identify the major hurdles in implementing change and identifying a way out to cope with the situation based on available literature on SMEs and change management. This study follows a synthesized literature review methodology and is a kind of review paper. In this research, literature that has been written on crisis management and especially over the COVID 19 has been reviewed. In this review analysis, previous studies regarding change management and the importance of SMEs in economic sustainability have been discussed. The paper is a review of existing literature and will identify how the organizations can survive through implementing change successfully. The study is significant for SMEs in the entire world. The study is useful for understanding the issues that are related to managing and implementing change in small and medium enterprises especially while facing contingencies. Finally, in this research, future researchers are guided to empirically test the factors identified in the findings of the study.
\end{abstract}

\title{
Keywords
}

Change Management, Implementing Change, Small and Medium Enterprises, COVID-19, Performance

\section{Introduction}

Coronavirus (COVID-19) has affected almost all the industries and has forced people to sit at home causing a huge socio-economic disaster (Ozili \& Arun, 2020). For the survival of businesses, sustainable income is compulsory (Alkhuzaie \& Asad, 2018) which has become a major challenge because of the cancellation of sports, religious, and cultural activities. Mainly, $81 \%$ of job providers and $66 \%$ of employees have negatively been influenced, as 436 million Small and Medium Enterprises (SMEs) are in jeopardy (International Labor Organization, 2020). The economy is dependent on the consumers and consumers are dependent on those SMEs, likewise, the performance of SMEs is dependent on the consumers (Asad \& Abid, 2018; Amir \& Asad, 2018; Asad, Iftikhar, \& Jafary, 2019). Thus, considering the importance of SMEs in the overall economy, it is very important to do every possible thing to keep the sector alive. In the current study, the 
issues that are currently being faced by the SMEs in sustaining during the time of crises have been identified, which will help the policymakers to handle those issues to control the disaster.

\subsection{Research Issue}

As per the estimates of the world bank the economy may face $-1 \%$ to $-1.5 \%$ growth in the current fiscal year. The severity of the issue can be understood because even in the UK $41 \%$ of enterprises have been closed and out of which 35\% may not reopen (Cusmano \& Raes, 2020). SMEs being the major supporter of the economy by contributing maximum proportion in employment generation, need to be focused seriously (Asad, Sharif, \& ALekam, 2016; Asad, Sharif, \& Alekam, 2016; Asad, Sharif, \& Hafeez, 2016; Haider, Asad, \& Fatima, 2017). Therefore, governments all over the world are paying special attention because of having their capacity of saving the nation from unemployment, poverty, and food insecurity. Like other countries, the economy of Pakistan has also been affected severely (Institute of Business Administration, 2020).

Furthermore, a decline between $2.9 \%$ to $2.4 \%$ is expected in the current fiscal year because of COVID-19 (OECD Interim Economic Assessment, 2020). European Union is expected to be at the top being affected by COVID-19 (United Nations Conference on Trade and Development, 2020) followed by the United States. COVID-19 is supposed to affect 1.2 million people (Bloomberg, 2020). In countries like Pakistan, the issue is getting critical, because people work on daily wages (Haider, Asad, \& Almansour, 2015) rather than having proper employment contracts like in developed countries (Asad \& Javaid, 2010), therefore, because of current situations majority of the workers are unable to earn both end meat and they are also not educated enough to raise their voice (Haider, Asad, \& Aziz, 2015). But the owners of SMEs are also unable to manage because they are also not able to pay the salaries because of a decline in the sales and operations. For survival in the current situations, it is compulsory to identify the innovative ways of doing business, and managing change and innovation is a big challenge (Abdin, 2020). Without implementing change, it is impossible to survive because all the businesses are adopting innovative ways nowadays and that's the only way out (Hadi \& Supardi, 2020).

\subsection{Significance and Objectives of the Study}

Considering the situation of Pakistan as the labor is not skilled and also considering the importance of the SME sector, this study has mainly focused on SMEs that require implementing and managing change, which is a must for their survival and survival of the overall economy. Moreover, considering the gap in the literature with respect to this special event, this research is 
going to fill the gap in the contingency theory that how in a particular situation where the contingency is related to life and health of human beings, how the businesses can survive by implementing and managing change successfully (Papadopoulos, Baltas, \& ElisavetBalta, 2020). The research will cover the literature on how the SMEs in Pakistan have been affected because of COVID-19 and will identify the need and importance of change for their survival in the current situations (Chethiyar, Vedamanikam, Das, Nair, \& Nair, 2020). The study is helpful in the identification of the areas that need to be focused on by the policymakers to control the deteriorating situation and uplifting the sector, as the sector has huge importance in employment and overall economic activities. Thus, the main objective is to identify those factors that are mainly causing issues in the adoption and implementation of change which is compulsory for the survival of SMEs in the current situation.

\section{Review of Related Literature}

The literature on the issue of COVID-19 is limited. All of the businesses, except very few related to medicine, are under crisis, except the one that focused on innovation and change (Asad \& Sharif, 2016; Asad, Rizwan, Shah, \& Munir, 2018; Fitriasari, 2020) and outfitting the prospects (Haider, Asad, Atiq, \& Fatima, 2017) for having good access to finances (Asad, Sharif, \& Alekam, 2016; Abrar-ul-Haq, Asad, Natarajan, Sankar, \& Asif, 2020). SMEs having financial access, utilize their marketing capabilities (Wang, Hong, Li, \& Gao, 2020) to survive in tough times. In this study, the available literature on SMEs and their need to implement change during the pandemic has been covered.

The economic effects of the Pandemic can be seen, as several people become jobless because of lockdowns (Salik, 2020). The investors are losing money because their strategies for analyzing stocks have failed (Asad \& Farooq, 2009; Shaker, Asad, \& Zulfiqar, 2018). According to SMEDA, 95\% of SMEs reported a reduction in operations and 92\% reported disruption in the supply chain and 23\% revealed a 100\% loss in exports (The Nation, 2020). Despite the steps of government for SMEs; including financial packages, relaxation in payments of utility bills, and easing conditions for loan repayments (Ganaie, Zafar, \& Seth, 2020) yet SMEs are deteriorating adversely due to the pandemic. The major reason behind this deterioration is unaccepting the fact that they must alter their way of doing business as per the situations (Chethiyar, Vedamanikam, Das, Nair, \& Nair, 2020). 
COVID-19 is causing many to become among the unemployed and those who are employed are suffering from information and communication overload which causes stress (Chethiyar, Asad, Kamaluddin, Ali, \& Sulaiman, 2019) as now everyone is exposed to excessive information regarding the economy and health. In the current situation, there is a need for social support to remain motivated (Asad, 2020) and learn change. In Pakistan SMEs lack human resource practices (Asad, Haider, Akhtar, \& Javaid, 2011), and because of organizational politics (Asad, Muhammad, Rasheed, Chethiyar, \& Ali, 2020) those who want to work, people do not let them work as they will also have to learn the new methods.

Thus, when change is mandatory social support is required (Shah \& Asad, 2018) to improve the motivation level of employees in learning new ways of doing business. Otherwise, employees feel chaos because of losing a job ( $\mathrm{Lu}, \mathrm{Wu}$, Peng, \& Lu, 2020) as businesses in order to reduce cost, violate contracts (Haider, Fatima, Asad, \& Ahmad, 2016). Because of Pandemic tourism and travel, stock markets, entertainment, and manufacturing sectors are on the hit list (Larsson \& Gustavsson, 2020) and so their employees. A noteworthy decline has been observed in remittances because the service sector has badly affected in GCC were a significant number of Pakistani work (Haider, Fatima, Asad, \& Ahmad, 2016; Chohan, 2020).

Owners of the SMEs are always interested in growth and stability (Almansour, Asad, \& Shahzad, 2016; Alkhuzaie \& Asad, 2018; Islam, 2020), but COVID-19 has jammed the wheel of the economy (Cusmano \& Raes, 2020) and has affected the SMEs across the globe. Traders expect growth during summers (Asad, 2010); however, orders have dropped down, resulting in a decline in foreign exchange earnings (The Express Tribune, 2020; Dawn, 2020). In such situations, SMEs need to take certain measures, for withstanding economic downturn. Entrepreneurs who do not adopt change, to remain stable, had to sell or revalue their assets (Asad, 2011; Asad \& Qadeer, 2014; Khalil, Asad, \& Khan, 2018). Reduction in economic activities is the major hurdle (Milzam, Mahardika, \& Amalia, 2020) it has affected the supply chain (McCann \& Myers, 2020). In order to prevent the closure of SMEs, financial institutions are providing support (Didier, Huneeus, Larrain, \& Schmukler, 2020) yet many enterprises are about to close because of a decline in sales ( $\mathrm{Lu}, \mathrm{Wu}$, Peng, \& Lu, 2020) and businesses have not adopted other methods to sale their products.

Innovative and entrepreneurial SMEs were relatively less affected by COVID-19 (Asad, Ahmad, Haider, \& Salman, 2018; Winarsih, Indriastuti, \& Fuad, 2020). Restricted traveling and lockdowns have caused the loss of jobs as people lack the skills required to manage in a challenging 
situation (Haider, Asad, Fatima, \& Abidin, 2017). Although enterprises are responsible for their employees (Haider, Asad, \& Fatima, 2017) yet because of the financial crisis, SMEs are unable to handle the situation. As worldwide, socio-economic response to this pandemic is drastic (Nicola, et al., 2020). Zakat and Qaradh Al- Hasan is supposed to be beneficial during the current situation (Syed, Khan, Raza Rabbani, \& Thalassinos, 2020), thus, even the mode of financing must be changed. Because of the high level of poverty (Asad, Haider, \& Fatima, 2018), SMEs need support. Another reason behind adverse situations is supply-side (Bizoza \& Sibomana, 2020) as SMEs usually have a lesser number of suppliers, and they are not providing them proper supplies, SMEs need to even change their supply chain mechanisms (Shabbir, Asad, Faisal, \& Salman, 2019).

Being small (Asad, Shabbir, Salman, Haider, \& Ahmad, 2018) and low in innovation (Asad, Rizwan, Shah, \& Munir, 2018; Sheikh, Asad, Ahmed, \& Mukhtar, 2020) during COVID-19, the performance of SMEs is declining more than that of any other sectors (Eggers, 2020). In Pakistan, due to the financial crisis government is unable to support the masses (Khan S. N., Asad, Fatima, Anjum, \& Akhtar, 2020), and even microfinance institutions that are necessary for SMEs (Khan, Haider, \& Asad, 2010) are not on strong footing (Malik, et al., 2020). The main reason behind all this decline is the lack of adaption of innovative methods in the current scenario. The above literature review highlights that majority of the SMEs throughout the world and especially in the developing countries (Zahra, Majeed, Mahmood, \& Asad, 2012) are on the verge of closure because they have not coped with the situation and have not implemented change with the changing requirement (Omar, Ishak, \& Jusoh, 2020).

\subsection{Underpinning Theory}

The current study deals with a situation that has threatened businesses throughout the world. All businesses must aggressively adopt contingency planning. The theory that supports such kind of research is contingency theory (Feldman, 1976). The event is contingent; however, the current study is enriching the theory by adding the importance of managing and implementing change in the theory, as the current usage of the theory was for the normal change (Battilana \& Casciaro, 2012), but, the current change is supposed to be a must for survival. As per the literature reviewed, till now the major contingencies dealt with the business are mainly the economic or business contingencies (Sheikh, Asad, \& Mukhtar, 2020; Tabash, Sheikh, \& Asad, 2020), however, this is the first of its kind that is causing life threats and severe health issues. 


\section{Methodology}

The purpose of this study was to identify the major hurdles being faced by the SMEs while implementing change during COVID-19. The paper followed a review methodology and identified the factors that might become a hurdle in implementing change during the pandemic. Detailed literature has been reviewed over the COVID-19 and SMEs, the performance of SMEs, change management, and hurdles faced by SMEs in implementing change. Therefore, a systematic review was conducted that ensures that all the factors that may act as a hurdle have been addressed.

\subsection{Research Limitations}

Like the limitations of any qualitative study this study also has certain limitations (Fatima \& Asad, 2018). The major limitation of the study was finding the appropriate literature, as the issue is current and a new of its type. The study has mainly focused on the literature on SMEs and the economic impact of COVID-19. The literature on SMEs especially regarding COVID is limited. Therefore, the available literature and the literature over management and implementation of change about SMEs have been utilized.

\section{Discussions and Analysis}

The purpose of this study was to understand the current situations that SMEs are facing worldwide and especially in Pakistan. The study aims to identify the strategies that need to be implemented to implement change successfully. Managing and implementing innovation or change in the large organizations is much easier than in the SMEs (Farrukh \& Asad, 2017; Shabbir, Shariff, Asad, Salman, \& Ahmad, 2018; Shabbir, Asad, Faisal, \& Salman, 2019). The literature of change suggests that change can be implemented through properly motivating employees and by increasing the pay scales, however, during a pandemic when all the organizations are facing a financial crisis, even maintaining the salaries is a big motivation for employees (Shah \& Asad, 2018). Human resource is the key to success (Haider, Asad, \& Fatima, 2017). Therefore, motivating people through facilitating them and guiding them about the adoption of the latest procedures is the best strategy to implement change successfully.

The resistance that might be faced during the adoption of the latest procedures can be at the systemic or at behavioral level. In this regard, the role of leadership, governance, and the top management or the ownership of the organization is very critical (Alkhuzaie \& Asad, 2018; Bashir \& Asad, 2018). By acknowledging the pain that employees face while implementing change, 
managers can motivate their employees. And only by implementing change successfully the sector can survive. The change process in any organization is a big challenge. It is a fundamental human nature that people resist change and need to be motivated properly. Whenever organizations implement change, usually human resources initially reject the new methods. During the time of crisis as in the case of COVID-19, any type of resistance by the employees may result in severe crisis. The resistance of the employees needs to be diluted through proper training and motivation, only then successful implementation of change is possible and then challenges can be converted into opportunities. The following flow chart shows the process that SMEs need to adopt in order to maintain or gain high performance.

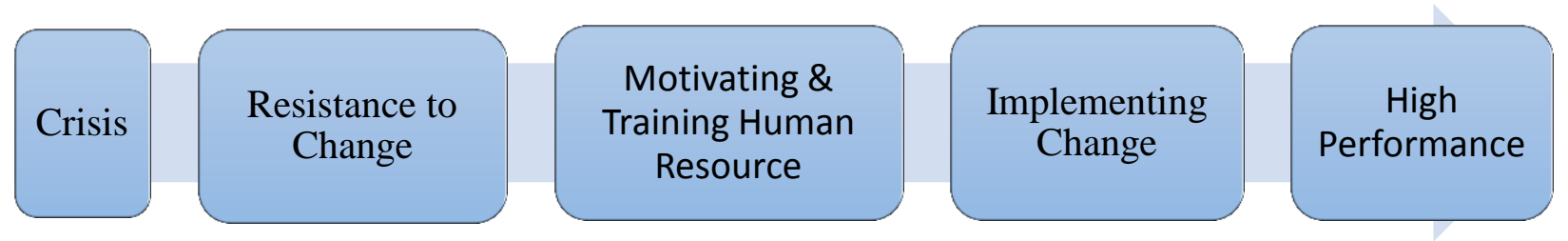

Figure 1: Flow Chart of Successful Change Management

Finally, financial support and training by the government are also very important, without the support of the government, the SME sector cannot play any significant role (Asad, Haider, \& Fatima, 2018; Israr, Asad, Altaf, \& Victor, 2020). The major issue of the sector is informal setups and lack of records due to a shortage of resources (Asad, Chethiyar, \& Ali, 2020), therefore, in such situations, the support of the government can play a significant role in the success and sustainability of the SMEs.

\subsection{Recommendations}

The current study is very important for managers and policymakers. This study highlighted the importance of change which is very important during a pandemic, especially for small and medium-sized businesses. The study is also important for the government authorities and policymakers that must address the issues that are being faced by the sector, because of the pandemic. The sector without the support of the government cannot survive and cannot sustain especially in a time of crisis.

\section{Conclusions}

The findings of the study and the literature review lead to the conclusion that without implementing change successfully, it is impossible to survive during a pandemic. In order to 
implement change successfully, it is compulsory to take a lot of care of the human resource (Asad, 2020). In SMEs especially in developing countries, human resources are not well managed (Asad, Haider, Akhtar, \& Javaid, 2011), and there are hardly systems for the management and development of human resources. Without managing human resources properly, it is difficult to manage the change.

\section{Future Directions}

The study opened several horizons for further studies in the field of crisis management. In the future, the researchers are suggested to conduct studies on differentiating the SMEs' performance on the basis of adopting and not adopting the change during the challenging time periods. The researchers may also conduct quantitative studies on identifying the impact of significant factors that may be controlled to avoid any kind of disaster in the SME sector. The findings also lead to further qualitative research for exploring the factors that need to be controlled by the SME owners as well as the policymakers to minimize the effect of Pandemic on SMEs.

\section{REFERENCES}

Abdin, J. (2020). Doing businesses during COVID-19 crisis and afterwards. Social Science Research Network, 1-3. https://doi.org/10.2139/ssrn.3577715

Abrar-ul-Haq, M., Asad, M., Natarajan, V., Sankar, J. P., \& Asif, M. U. (2020). 2020 Microfinance and empowerment: A case study on beneficiaries of a community development program. Hamdard Islamicus, 43(S1), 378-388.

Alkhuzaie, A. S., \& Asad, M. (2018). Operating cashflow, corporate governance, and sustainable dividend payout. International Journal of Entrepreneurship, 22(4), 1-9.

Almansour, A. Z., Asad, M., \& Shahzad, I. (2016). Analysis of corporate governance compliance and its impact over return on assets of listed companies in Malaysia. Science International, 28(3), 2935-2938.

Amir, A., \& Asad, M. (2018). Consumer's Purchase Intentions towards automobiles in Pakistan. Open Journal of Business and Management, 6, 202-213. https://doi.org/10.4236/ojbm.2018.61014 
Asad, M. (2010). Perception of trader towards international trade: A diagnostic study. Paradigms; A Journal of Commerce, Economics, and Social Sciences, 4(1), 48-63. https://doi.org/10.24312/paradigms040103

Asad, M. (2011). Working capital management and corporate performance of textile sector in Pakistan. Paradigms: A Research Journal of Commerce, Economics and Social Sciences, 6(1), 100-114. doi:10.24312/paradigms060101

Asad, M. (2020). Human resource practices and employee turnover intentions: Do organizational commitment mediates and social support moderates the relationship? International Journal of Psychosocial Rehabilitation, 24(7), 5685-5695.

Asad, M., \& Abid, U. (2018). CSR practices and customer's loyalty in restaurant industry: Moderating role of gender. NUML International Journal of Business \& Management, 13(2), 144-155.

Asad, M., \& Farooq, A. (2009). Factors influencing KSE 100 index / share prices. Pardigms A Journal of Commerce, Economics, and Social Sciences, 3(1), 34-51. doi:10.24312/paradigms030102

Asad, M., \& Qadeer, H. (2014). Components of working capital and profitability: A case of fuel and energy sector of Pakistan. Pardigms A Journal of Commerce, Economics, and Social Sciences, 8(1), 50-64. doi:10.24312/paradigms08010

Asad, M., \& Sharif, M. N. (2016). Entrepreneurial orientation market orientation and performance of SMEs moderating effect of network ties. 2nd International Conference on Business Management. Jakarta.

Asad, M., Ahmad, I., Haider, S. H., \& Salman, R. (2018). A critical review of islamic and conventional banking in digital era: A case of Pakistan. International Journal of Engineering \& Technology, 7(4.7), 57-59. https://doi.org/10.14419/ijet.v7i4.7.20382

Asad, M., Chethiyar, S. D., \& Ali, A. (2020). Total quality management, entrepreneurial orientation, and market orientation: Moderating effect of environment on performance of SMEs. Paradigms; A Research Journal of Commerce, Economics, and Social Sciences, 14(1), 102108.

Asad, M., Haider, S. H., \& Fatima, M. (2018). Corporate social responsibility, business ethics, and labor laws: A qualitative analysis on SMEs in Sialkot. Journal of Legal, Ethical and Regulatory Issues, 21(3), 1-7. 
Asad, M., Haider, S. H., Akhtar, M. B., \& Javaid, M. U. (2011). Human Resource Practices and Enterprise Performance in Small and Medium Enterprises of Pakistan. First International Conference on Contemporary Issues of Business (pp. 1-18). Lahore: Comsats.

Asad, M., Iftikhar, K., \& Jafary, A. Y. (2019). Relationship between capital structure and financial performance of textile sector companies. Kashmir Economic Review, 28(1), 39-52.

Asad, M., Muhammad, R., Rasheed, N., Chethiyar, S. D., \& Ali, A. (2020). Unveiling antecedents of organizational politics: An exploratory study on science and technology universities of Pakistan. International Journal of Advanced Science and Technology, 29(6s), 2057-2066.

Asad, M., Rizwan, A., Shah, M., \& Munir, A. (2018). Impact of innovation practices on sustainable performance of SMEs. Herald National Academy of Managerial Staff of Culture and Arts, 3, 537-546.

Asad, M., Shabbir, M. S., Salman, R., Haider, S. H., \& Ahmad, I. (2018). Do entrepreneurial orientation and size of enterprise influence the performance of micro and small enterprises? A study on mediating role of innovation. Management Science Letters, 8(10), 1015-1026. https://doi.org/10.5267/j.msl.2018.7.008

Asad, M., Sharif, M. N., \& Alekam, J. M. (2016). Moderating role of entrepreneurial networking on the relationship between access to finance and performance of micro and small enterprises. Paradigms; A Research Journal of Commerce, Economics, and Social Sciences, 10(1), 1-13. https://doi.org/10.24312/paradigms100101

Asad, M., Sharif, M. N., \& ALekam, J. M. (2016). Moderating role of entrepreneurial networking on the relationship between entrepreneurial orientation and performance of MSEs in Punjab Pakistan. Science International, 28(2), 1551-1556.

Asad, M., Sharif, M. N., \& Hafeez, M. (2016). Moderating effect of network ties on the relationship between entrepreneurial orientation, market orientation, and performance of MSEs. Paradigms: A Research Journal of Commerce, Economics, and Social Sciences, 10(2), 6976. https://doi.org/10.24312/paradigms100207

Bashir, A., \& Asad, M. (2018). Moderating effect of leverage on the relationship between board size, board meetings and performance: A study on textile sector of Pakistan. American Scientific Research Journal for Engineering, Technology, and Sciences (ASRJETS), 39(1), 19-29. 
Battilana, J., \& Casciaro, T. (2012). Change agents, networks, and institutions: A contingency theory of organizational change. Academy of Management Journal, 55(2), 381-398. https://doi.org/10.5465/amj.2009.0891

Bizoza, A., \& Sibomana, S. (2020). Indicative socio-economic impacts of the novel coronavirus (Covid-19) outbreak in Eastern Africa: Case of Rwanda. Social Science Research Network, 1-23. https://doi.org/10.2139/ssrn.3586622

Bloomberg. (2020, March 23). European Retailers Scrap \$1.5 Billion of Bangladesh Orders. p. 1.

Chethiyar, S. D., Asad, M., Kamaluddin, M. R., Ali, A., \& Sulaiman, M. A. (2019). Impact of information and communication overload syndrome on the performance of students. Opción, 24, 390-405.

Chethiyar, S. D., Vedamanikam, M., Das, E. S., Nair, R. N., \& Nair, D. N. (2020). Winning the COVID war as responsive Malaysian citizen: Social confirmity, social compliance, and social obedience. LIFE: International Journal of Health and Life-Sciences, 6(2), 1-10. https://doi.org/10.20319/lijhls.2020.62.0110

Chohan, U. W. (2020). Forecasting the economic impact of coronavirus on developing countries: Case of Pakistan. CASS Working Papers on Economics \& National Affairs, 1-26. https://doi.org/10.2139/ssrn.3563616

Cusmano, L., \& Raes, S. (2020, May 19). OECD Policy Responses to Coronavirus (COVID-19); Coronavirus (COVID-19): SME policy responses. Retrieved from OECD Better Policies for Better Lives: http://www.oecd.org/coronavirus/policy-responses/coronavirus-covid-19-smepolicy-responses-04440101/\#section-d1e160

Dawn. (2020, May 18). Pakistan's top export destinations have been devastated by Covid-19. What does it mean for our trade? With a majority of Pakistan's exports destined for most-affected countries, traders must diversify to other items., p. 1.

Didier, T., Huneeus, F., Larrain, M., \& Schmukler, S. L. (2020). Financing Firms in Hibernation during the COVID-19 Pandemic. World Bank Group. Chile: World Ban Group. $\underline{\text { https://doi.org/10.1596/1813-9450-9236 }}$

Eggers, F. (2020). Masters of disasters? Challenges and opportunities for SMEs in times of crisis. Journal of Business Research, 116, 199-208. https://doi.org/10.1016/j.jbusres.2020.05.025

Farrukh, W., \& Asad, M. (2017). The determinants of capital structure: A study on cement sector of Pakistan. International Journal of Management Sciences and Business Research, 6(2), 16-26. 
Fatima, S. Z., \& Asad, M. (2018). Disposal of hospital wastage in Pakistan: A qualitative research. Advances in Social Sciences Research Journal, 5(3), 37-42. https://doi.org/10.14738/assrj

Feldman, D. C. (1976). A Contingency Theory of Socialization. Administrative Science Quarterly, 21(3), 433-452. https://doi.org/10.2307/2391853

Fitriasari, F. (2020). How do Small and Medium Enterprise (SME) survive the COVID-19 outbreak? Jurnal of Inovasi Ekonomi, 5(2), 53-62. https://doi.org/10.22219/jiko.v5i3.11838

Ganaie, M. A., Zafar, F., \& Seth, N. J. (2020). Impact of COVID-19 (Coronavirus) on Small and Medium Enterprises (SMEs) in Pakistan. ResearchGate, 1-32.

Hadi, S., \& Supardi. (2020). Revitalization strategy for small and medium enterprises after corona virus disease pandemic (Covid-19) in Yogyakarta. Journal of Xi'an University of Architecture \& Technology, 8(4), 4068-4076.

Haider, S. H., Asad, M., \& Almansour, A. Z. (2015). Factors influencing growth of cottage industry in Punjab, Pakistan: Cottage industry owners' perspective. Paradigms: A Research Journal of Commerce, Economics, and Social Sciences, 9(1), 78-87. https://doi.org/10.24312/paradigms090105

Haider, S. H., Asad, M., \& Aziz, A. (2015). A survey on the determinants of entrepreneurial training effectiveness among micro finance institutions of Malaysia. Mediterranean Journal of Social Sciences, 6(6 S4), 396-403. https://doi.org/10.5901/mjss.2015.v6n6s4p396

Haider, S. H., Asad, M., \& Fatima, M. (2017). Entrepreneurial orientation and business performance of manufacturing sector small and medium scale enterprises of Punjab Pakistan. European Business and Management, 3(2), 21-28. https://doi.org/10.11648/j.ebm.20170302.12

Haider, S. H., Asad, M., \& Fatima, M. (2017). Responsibility of global corporations towards human resource to attain competitive advantage: A review. Journal of Research in Administrative Sciences, 6(2), 9-12. https://doi.org/10.47609/JRAS2017v6i2p3

Haider, S. H., Asad, M., Atiq, H., \& Fatima, M. (2017). Mediating role of opportunity recognition between credit, savings and performance of micro and small enterprises in Pakistan. Journal of Advanced Research in Business and Management Studies, 7(2), 91-99.

Haider, S. H., Asad, M., Fatima, M., \& Abidin, R. Z. (2017). Microfinance and performance of micro and small enterprises: Does training have an impact. Journal of Entrepreneurship and Business Innovation, 4(1), 1-13. https://doi.org/10.5296/jebi.v4i1.10566 
Haider, S. H., Fatima, M., Asad, M., \& Ahmad, A. Z. (2016). A study on the issues of employment contracts and practices of employment contracts in UAE. Paradigms: A Journal of Commerce, Economics, and Social Sciences, 10(1), 58-64. https://doi.org/10.24312/paradigms100105

Institute of Business Administration. (2020). Short Notes on the Economy during the Covid-19 Crisis. Karachi: Institute of Business Administration.

International Labor Organization. (2020, April 29). COVID-19 and the world of work. Third edition updated estimates and analysis. ILO Monitor, pp. 1-23.

Islam, A. (2020). Factors affecting sustainable business growth of SMEs during Covid-19 crisis: The mediating role of strategic entrepreneurship practices. Emerald Open Research.

Israr, A., Asad, M., Altaf, N., \& Victor, S. (2020). Training effectiveness and performance of micro small and medium sized enterprises. Hamdard Islamicus, 43(S1), 349-358.

Khalil, R., Asad, M., \& Khan, S. N. (2018). Management motives behind the revaluation of fixed assets for sustainability of entrepreneurial companies. International Journal of Entrepreneurship, 22(Special), 1-9.

Khan, A. A., Haider, S. H., \& Asad, M. (2010). Impact assessment of Microfinance: A case study of Akhuwat. Faculty of Commerce, Research and Development Center. Lahore: University of Central Punjab.

Khan, S. N., Asad, M., Fatima, A., Anjum, K., \& Akhtar, K. (2020). Outsourcing internal audit services; A review. International Journal of Management, 11(8), 503-517.

Larsson, S., \& Gustavsson, S. (2020). Marketing Innovation for SMEs during COVID-19 Pandemic: A case study of the hospitality industry in Norrbotten. 1-68: Department of Business Administration, Technology and Social Sciences, Luleå University of Technology.

Lu, Y., Wu, J., Peng, J., \& Lu, L. (2020). The perceived impact of the Covid-19 epidemic: evidence from a sample of 4807 SMEs in Sichuan Province, China. Environmental Hazards, 19(3), 118. https://doi.org/10.1080/17477891.2020.1763902

Malik, K., Meki, M., Morduch, J., Ogden, T., Ogden, T., \& Said, F. (2020). COVID-19 and the future of Microfinance: Evidence and insights from Pakistan. Oxford Review of Economic Policy, Forthcoming, 1-43. https://doi.org/10.2139/ssrn.3615077

McCann, F., \& Myers, S. (2020). COVID-19 and the transmission of shocks through domestic supply chains. Dublin: Central Bank of Ireland. 
Milzam, M., Mahardika, A., \& Amalia, R. (2020). Corona virus pandemic impact on sales revenue of Micro Small and Medium Enterprises (MSMEs) in Pekalongan city, Indonesia. Journal of Vocational Studies on Applied Research, 2(1), 7-10.

Nicola, M., Alsafi, Z., Sohrabi, C., Kerwan, A., Al-Jabir, A., Iosifidis, C., . . Agha, R. (2020). The socio-economic implications of the coronavirus pandemic (COVID-19): A review. International Journal of Surgery, 78, 185-193. https://doi.org/10.1016/j.ijsu.2020.04.018

OECD Interim Economic Assessment. (2020). Coronavirus: The world economy at risk. Paris: OECD.

Omar, A. R., Ishak, S., \& Jusoh, M. A. (2020). The impact of Covid-19 Movement Control Order on SMEs' businesses and survival strategies. Geografia-Malaysian Journal of Society and Space, 16(2), 139-150. https://doi.org/10.17576/geo-2020-1602-11

Ozili, P. K., \& Arun, T. (2020). Spillover of COVID-19: Impact on the global economy. Social Science Research Network, 1-27. https://doi.org/10.2139/ssrn.3562570

Papadopoulos, T., Baltas, K. N., \& ElisavetBalta, M. (2020). The use of digital technologies by small and medium enterprises during COVID-19: Implications for theory and practice. International Journal of Information 1-4. https://doi.org/10.1016/j.ijinfomgt.2020.102192

Salik, M. M. (2020, May 02). Issue Brief on "Impact of Covid-19 on Economy of Pakistan". Institute of Strategic Studies Islamabad, p. 1.

Shabbir, M. S., Asad, M., Faisal, M., \& Salman, R. (2019). The relationship between product nature and supply chain strategy: An empirical evidence. International Journal of Supply Chain Management, 8(2), 654-658.

Shabbir, M. S., Shariff, P. D., Asad, M., Salman, R., \& Ahmad, I. (2018). Time-frequency relationship between innovation and energy demand in Pakistan: Evidence from Wavelet Coherence Analysis. International Journal of Energy Economics and Policy, 8(5), 251-258.

Shah, M., \& Asad, M. (2018). Effect of motivation on employee retention: Mediating role of perceived organizational support. European Online Journal of Natural and Social Sciences, 7(2), 511-520.

Shaker, R. Z., Asad, M., \& Zulfiqar, N. (2018). Do predictive power of Fibonacci retracements help the investor to predict future? A study of Pakistan Stock Exchange. International Journal of Economics and Financial Research, 4(6), 159-164. 
Sheikh, U. A., Asad, M., \& Mukhtar, U. (2020). Modelling asymmetric effect of foreign direct investment inflows, carbon emission and economic growth on energy consumption of South Asian region: A symmetrical and asymmetrical panel autoregressive distributive lag model approach. Accountancy Business and the Public Interest, 19, 193-221.

Sheikh, U. A., Asad, M., Ahmed, Z., \& Mukhtar, U. (2020). Asymmetrical relationship between oil prices, gold prices, exchange rate, and stock prices during global financial crisis 2008: Evidence from Pakistan. Cogent Economics \& Finance, 8(1), 1-20. https://doi.org/10.1080/23322039.2020.1757802

Syed, M. H., Khan, S., Raza Rabbani, M., \& Thalassinos, Y. E. (2020). An artificial intelligence and NLP based Islamic FinTech model combining Zakat and Qardh-Al-Hasan for countering the adverse impact of COVID 19 on SMEs and individuals. International Journal of Economics and Business Administration, 8(2), 351-364. https://doi.org/10.35808/ijeba/466

Tabash, M. I., Sheikh, U. A., \& Asad, M. (2020). Market miracles: Resilience of Karachi stock exchange index against terrorism in Pakistan. Cogent Economics \& Finance, 8(1), 1-23. doi: https://doi.org/10.1080/23322039.2020.1821998

The Express Tribune. (2020, April 20). Covid-19 and impact on economy. Covid-19 and impact on econom, p. 1. https://doi.org/10.32983/2222-0712-2020-1-20-26

The Nation. (2020, May 08). LETTER: Supporting SMEs during COVID19. LETTER: Supporting SMEs during COVID19, p. 1.

United Nations conference on Trade and Development. (2020). Global Trade. Geneva: UNCTD.

Wang, Y., Hong, A., Li, X., \& Gao, J. (2020). Marketing innovations during a global crisis: A study of China firms' response to COVID-19. Journal of Business Research, 116, 214-220. https://doi.org/10.1016/j.jbusres.2020.05.029

Winarsih, Indriastuti, M., \& Fuad, K. (2020). Impact of Covid-19 on digital transformation and sustainability in Small and Medium Enterprises (SMEs): A conceptual framework. Complex, Intelligent, and Software Intensive Systems, 471-476. https://doi.org/10.1007/978-3-030$\underline{50454-0 \_48}$

Zahra, K., Majeed, K., Mahmood, A., \& Asad, M. (2012). Impact assessment of community participation in solid waste management projects in selected areas of Faisalabad city. Journal of Urban Planning and Development, 138(4), 319-327. https://doi.org/10.1061/(ASCE)UP.1943-5444.0000127 